\title{
ANALISIS STRATEGI PEMASARAN TERHADAP KAMERA PONSEL SAMSUNG BERDASARKAN PERSEPSI KONSUMEN DENGAN MENGGUNAKAN METODE MULTIDIMENSIONAL SCALING
}

\author{
A. Z. Wattimena ${ }^{1}$, E. R. Persulessy ${ }^{2}$, M. J. Masbaitubun ${ }^{3}$ \\ 1,2,3 Jurusan Matematika, Fakultas MIPA, Universitas Pattimura \\ Jalan Ir. M. Putuhena, Kampus Unpatti, Poka, Ambon, Indonesia \\ e-mail: ${ }^{1}$ az.wattimena@staff.unpatti.ac.id; ${ }^{3}$ kellotokyar4241@gmail.com
}

\begin{abstract}
Abstrak
Dewasa ini berbagai macam produk kamera ponsel terus bermunculan dengan keunggulan masing-masing. Trend membanjirnya merek-merek ponsel baru di Indonesia, menjadikan persaingan di sektor ini semakin menarik. Kamera ponsel Samsung yang berhasil menyaingi Sony, Oppo dan Lenovo membuat banyak pembicaraan dikalangan pengguna gadget yang menimbulkan rasa ingin tahu sehingga dapat merangsang minat beli. Salah satu jalan untuk meraih keunggulan kompetisi berkelanjutan adalah dengan membentuk citra merek. Tujuan dari penelitian ini adalah untuk mengetahui pengaruh secara parsial maupun simultan variabel bebas citra merek yang terdiri dari jenis-jenis asosiasi merek $\left(X_{1}\right)$, dukungan asosiasi merek $\left(X_{2}\right)$, kekuatasn asosiasi merek $\left(X_{3}\right)$, dan keunikan asosiasi merek $\left(X_{4}\right)$ terhadap variabel terikat loyalitas konsumen. Populasi dalam penelitian ini adalah pengunjung yang berada di ambon city center (ACC). Sedangkan sampel dalam penelitian ini adalah 155 responden dengan teknik pengambilan sampel yaitu metode teori dari Naresh K. Malhotra. Dapat disimpulkan bahwa citra merek menentukan tingkat loyalitas konsumen dalam pembelian Kamera ponsel Samsung.
\end{abstract}

Kata Kunci: kamera Ponsel Samsung, kualitas, persepsi konsumen

\section{ANALYSIS OF MARKETING STRATEGY ON SAMSUNG CAMERA BASED ON CONSUMER PERCEPTION USING MULTIDIMENSIONAL SCALING METHOD}

\begin{abstract}
Today various camera phone products continue to emerge with their respective advantages. Trends in the flood of new mobile phone brands in Indonesia, making the competition in this sector more interesting. Samsung's camera phone that successfully rival sony, oppo and lenovo make a lot of talk among gadget users that cause curiosity so it can stimulate buying interest. One way to achieve sustainable competitive advantage is to shape the brand image. The purpose of this research is to know the partial and simultaneous influence of independent variables of brand image consisting of types of brand association $\left(X_{1}\right)$, brand association support $\left(X_{2}\right)$, strength of brand association $\left(X_{3}\right)$, and uniqueness of brand association $\left(X_{4}\right)$ dependent variable of consumer loyalty. The population in this study is the visitors in ambon city center (ACC). While the sample in this study is 155 respondents with sampling technique that is the method of Naresh K Malhotra. It can be concluded that the brand image determines the level of consumer loyalty in the purchase of Samsung Camera phones.
\end{abstract}

Keywords: Samsung handphone camera, quality and consumer perception

\section{Pendahuluan}

Pada era globalisasi dan perdagangan bebas menyebabkan arus teknologi, informasi, dan produk semakin cepat. Konsumen sebagai pengguna teknologi dihadapkan oleh berbagai pilihan yang menarik dari produk teknologi, seperti produk kamera ponsel samsung. Produk kamera ponsel samsung merupakan teknologi yang perkembangannya cukup pesat. Setiap tahunnya, jenis kamera ponsel Samsung, kualitas, 
dan persepsi konsumen ponsel baru diluncurkan oleh perusahaan pengembangan ponsel dengan berbagai model dan pilihan yang menarik. Peluncuran berbagai model dan pilihan jenis ponsel yang menarik itu diciptakan oleh perusahaan dengan tujuan untuk memenuhi keinginan konsumen yang berubah setiap saat. Dengan berbagai pilihan jenis produk kamera ponsel Samsung tersebut menyebabkan konsumen menjadi teliti dalam memilih jenis produk kamera ponsel Samsung. Banyak faktor yang menjadi pertimbangan konsumen dalam memilih jenis produk kamera ponsel samsung, diantaranya adalah bentuk, fasilitas, pengoperasian, dan lain-lain. Untuk dapat bersaing dan menarik konsumen agar menggunakan produk kamera samsung yang diproduksinya, perusahaan harus memperhatikan secara teliti faktor yang menjadi pertimbangan konsumen. Pertimbangan terhadap faktor tersebut yang menyebabkan timbulnya inovasi teknologi produk kamera ponsel Samsung.

Kamera ponsel Samsung adalah salah satu penyedia terbesar di dunia teknologi dimulai sebagai perusahaan perdagangan ekspor berbagai produk terbesar dari Korea Selatan ke Beijing, Cina dan bahkan ke negera lain salah satunya di indonesia. Kamera ponsel samsung didirikan oleh Lee Byung-chul pada tahun 1938, Samsung secara bertahap hingga saat ini berkembang menjadi korporasi multinasional. Sejarah kamera ponsel Samsung pada akhir 1980-an dan awal 1990-an, kamera Samsung berinvestasi dalam penelitian dan pengembangan, investasi yang penting dalam mendorong perusahaan untuk terdepan dalam industri elektronik global. Samsung mulai bangkit sebagai perusahaan internasional pada 1990-an hingga sekarang. Kamera ponsel Samsung mengungguli Sony, Oppo, dan Lenovo sebagai salah satu merek yang paling populer di dunia konsumen pada tahun 2004 dan 2005, serta peringkat ke 19 di dunia secara keseluruhan. Samsung menjadi perusahaan terbesar kedua setelah nokia dengan volume dunia produsen ponsel terutama pangsa pasar terkemuka di amerika utara dan eropa barat. Kesuksesan Samsung di dunia smartphone dimulai pada bulan 27 April 2009, kamera ponsel Samsung meluncurkan ponsel pertamanya yakni kamera ponsel Samsung i7500 yang selanjutnya keberhasilan kamera ponsel Samsung dimulai dengan peluncuran kamera ponsel Samsung pada tahun 2010 dan tingkat penjualan ini pun cukup tinggi serta fenomena ini menjadi sejarah bagi Samsung sendiri yang membawa posisi tertinggi menjadi urutan pertama yang selama ini diduduki oleh kamera sony, oppo dan lenovo sebagai vendor penjualan ponsel terbaik setelah peluncuran kamera ponsel Samsung.

Pemasaran adalah suatu proses social dan manejerial dimana individu dan kelompok mendapatkan kebutuhan dan keinginan mereka dengan menciptakan menawarkan dan bertukar sesuatu yang bernilai satu sama lain [4]. Perilaku konsumen mempunyai beberapa pengertian sebagai berikut: "Perilaku konsumen adalah tindakan yang langsung terlibat dalam mendapatkan, mengkonsumsi dan menghabiskan produk dan jasa, termasuk proses keputusan yang mendahului tindakan ini" [5]. Para penjual sebenarnya tidak banyak mengetahui tentang apa yang berada dalam benak seorang pembeli pada waktu sebelum, sedang dan setelah membeli sesuatu. Studi atas perilaku konsumen melibatkan suatu pemahaman atas motivasi dan persepsi.

Motivasi adalah suatu dorongan dari dalam yang diakibatkan oleh beberapa rangsangan (stimulus) dari luar yang menyebabkan seseorang bertindak dalam berbagai bentuk. Sedangkan Persepsi adalah sebagai kelanjutan dari motivasi yang merupakan factor penentu dalam pemilihan suatu produk."Persepsi adalah proses dimana seseorang memilih, mengorganisasikan, mengartikan masukan informasi untuk menciptakan suatu gambaran yang berarti di dunia ini” [7]. Keputusan seorang konsumen untuk memodifikasi, menunda, atau menghindari suatu keputusan pembelian sangat dipengaruhi oleh risiko yang dirasakan. Pembelian yang mahal melibatkan suatu pengambilan risiko. Besarnya risiko yang dirasakan berbeda-beda menurut jumlah uang yang dikeluarkan, besarnya ketidak pastian atribut, dan besarnya kepercayaan diri konsumen.

\section{Tinjauan Pustaka}

\subsection{Pengertian Multidimensional scaling}

Multidimensional scaling merupakan salah satu prosedur untuk menmetakan para kosumen berdasarkan suatu kemiripan secara visual dalam suatu giometri, peta giometri tersebut yang disebut Perceptual Map hal ini karena berhubungan dengan pembuatan map untuk menggambarkan posisi sebuah objek dengan objek lainya berdasarkan kemiripan objek-objek tersebut. MDS juga digunakan untuk mengetahui interdepensi atau saling ketergantungan antara varibel atau data. Multidimensional scaling adalah bagian dari teknik multivariate yaitu teknik interdependence yang berfokus pada objek [1].

\subsection{Analisis kluster}

Analisis kluster pada prinsipnya digunakan untuk mereduksi data yaitu proses untuk meringkas sejumlah variabel menjadi lebih sedikit dan menamakannya dengan kluster. Pada riset pemasaran, kluster 
biasanya digunakan untuk melakukan proses segmentasi sejauh respon den (konsumen) berdasarkan ciri-ciri sejumlah atribut yang ada (Santoso, 2002). Misal diamati dua obyek yang mempunyai p-sistem koordinat dimensi pada masing-masing obyek. Sebelum dilakukan pengelompokan, terlebih dahulu ditentukan kemiripan sifat antar obyek yang sering, digunakan adalah jarak Euklidean (Euclidean Distance) antara dua obyek.

Jarak Euclidean antara dua obyek $\chi$ dan $y$ dalam dimensi $p$ dirumuskan sebagai berikut:

$$
d=\left[\sum_{i=1}^{P}\left(X_{i}-Y_{i}\right)^{2}\right]^{1 / 2}
$$

Semakin kecil nilai $d$, semakin besar kemiripan antara kedua obyek tersebut, demikian juga sebaliknya, semakin besar nilai $d$, maka semakin kecil kemiripan antara kedua obyek tersebut.

\subsection{Analisa Tabulasi Silang (Crosstab)}

Crosstab (tabulasi silang) menyajikan data dalam bentuk tabulasi yang meliputi baris dan kolom. Dengan demikian, ciri tabulasi silang adalah adanya dua variable atau lebih yang mempunyai hubungan secara deskriptif. Data untuk penyajian tabulasi silang pada umumnya adalah data kualitatif, khususnya yang berskala nominal, sepertihubungan antara gender dengan usia, berapa komposisi laki-laki untuk setiap range usia dan lainnya. (Santoso, 2002)

Ada dua pengujian untuk menginterprestasikan data pada tabulasi silang adalah sebagai berikut:

\section{Chi-Square}

Uji Chi-square ini digunakan untuk menguji singnifikasi perbedaan antara dua kelompok yangin dependen. Hipotesis yang akan diuji mengatakan bahwa kedua kelompok itu berbeda dalam hal karakteristik tertentu, dengan demikian perbedaan itu berhubungan dengan frekuensi relatif masuknya anggota-anggota kelompok (dua kelompok) kedalam beberapa kategori (dua atau lebih). Cara mengoperasikan uji Chi-square $\left(X_{2}\right)$, pertama disusun frekuensi-frekuensi dalam kategori-kategori dalam suatu table kontingensi $r \times k(r$ menunjukkan baris dan $k$ menunjukkan kolom).

Rumus yang digunakan adalah sebagai berikut:

$$
X^{2}=\sum_{i=1}^{r} \sum_{i=1}^{k} \frac{\left(O_{i j-} E_{i j}\right)^{2}}{F_{i j}}
$$

Dimana:

$\sum_{i=1}^{r}=$ Jumlah semua baris (r)

$\sum_{i=1}^{k}=$ Jumlah semua kolom $(\mathrm{k})$

$O_{i j}=$ Frekuensi pengamatan (observasi) dari baris ke-i pada kolom ke-j

$E_{i j} \quad=$ Frekuensi diharapankan (teoritis) dari baris ke-i pada kolom ke-j

$E_{i j}=$ diperoleh dengan: $\left(n_{i}\right)\left(n_{j}\right) / n$

\section{Index of Agreement}

Pada tahap ini pengujian dilakukan untuk mengukur asosiasi dari variabel yang diteliti, asosiasi dinyatakan signifikan bila secara statistic dinyatakan ada asosiasi yang memiliki kekuatan yang cukup. Metode perhitungan Indexof Agreement yang umum dilakukan untuk kasus tabulasi silang dengan $r$ baris dan $k$ kolom adalah koefisien kontingensi. Koefisien kontingensi $c$ adalah suatu ukuran derajat hubungan, asosiasi, atau dependensi dari klasifikasi-klasifikasi dalam tabel kontingensi $r x k$.

Rumus koefisiensi kontingensi (Coefficient of Contingency) tersebut dinyatakan sebagi berikut: 
Dimana:

$$
C=\sqrt{\frac{X^{2}}{X^{2}+n}}
$$

$$
\begin{aligned}
& X^{2}=\text { nilai Chi-square } \\
& N=\text { besar sampel }
\end{aligned}
$$

\subsection{Multi Dimensional Scalling (MDS)}

Multi dimensional scaling adalah bagian dari teknik multivariate yaitu teknik interdependence yang berfokus pada objek [1]. Multivariate techniques diklasifikasikan menjadi:

1. Depedence Techniques yaitu jenis teknik yang terdiri dari satu atau lebih variable terikat. Aplikasinya terdapat beberapa metode seperti yang terlihat dalam gambar.

2. Interdepedence Techniques yaitu teknik yang memfokuskan analisa pada variable atau pada objek penelitian. MDS adalah salah satu metode analisis yang berasal dari aplikasi terkini.

Berikut ini terdapat pembagian dari teknik multivariate:

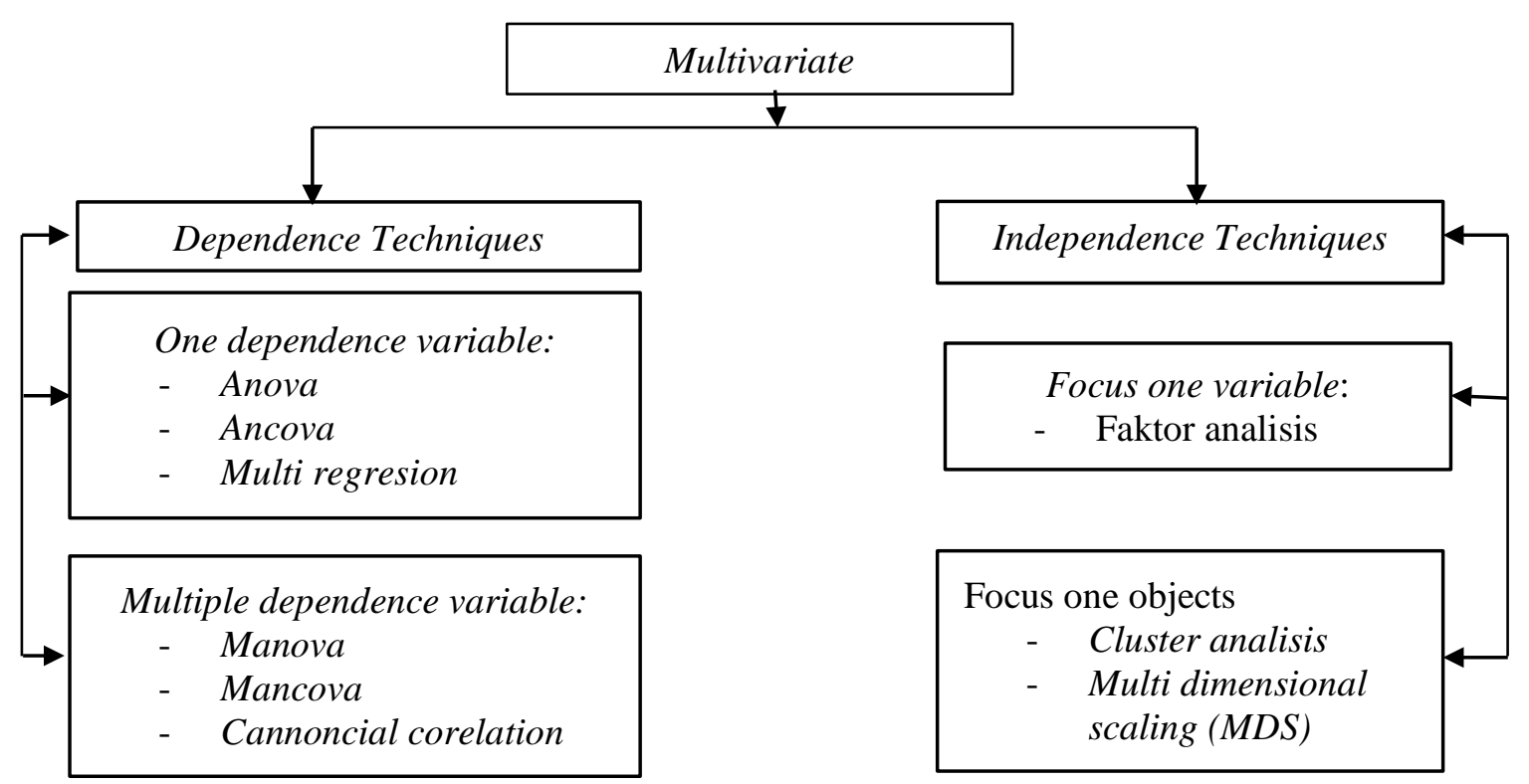

Gambar 1. Teknik Multivariate

\section{Hasil Penelitian}

Jumlah responden yang dijadikan sampel dalam penelitian ini adalah berjumlah 155 orang. Adapun gambaran terhadap responden diklasifikasikan berdasarkan usia, jenis kelamin, pendidikan, pekerjaan, pendapatan. Berdasarkan jumlah responden yang dijadikan sampel dalam penelitian ini diperoleh data sebagai berikut:

Tabel 1. Karakterstik Responden Berdasarkan Umur

\begin{tabular}{|c|c|c|}
\hline \multirow{2}{*}{ Usia } & $\begin{array}{c}\text { Jumlah } \\
\text { (orang) }\end{array}$ & $\begin{array}{c}\text { Percent } \\
\text { (\%) }\end{array}$ \\
\hline >18-20 tahun & 101 & 65.16 \\
\cline { 2 - 3 } 20-30 tahun & 36 & 23.22 \\
\cline { 2 - 3 }$>$ 30 tahun & 18 & 11.61 \\
\hline Total & 155 & 100.0 \\
\hline
\end{tabular}

Berdasarkan jumlah responden yang dijadikan sampel dalam penelitian ini diperoleh data sebagai berikut: 
Tabel 2. Karakterstik Responden Berdasarkan Jenis kelamin

\begin{tabular}{|c|c|c|c|}
\hline Jenis Kelamin & $\begin{array}{c}\text { Jumlah } \\
\text { (orang) }\end{array}$ & $\begin{array}{c}\text { Percent } \\
\text { (\%) }\end{array}$ & $\begin{array}{c}\text { Valid } \\
\text { Percent }\end{array}$ \\
\hline Laki-laki & 71 & 45.80 & 45.80 \\
\hline Perempuan & 84 & 54.19 & 54.19 \\
\hline Total & 155 & 100.0 & 100.0 \\
\hline
\end{tabular}

Jumlah responden menurut tingkat pendidikan dapat dilihat pada Tabel 3, berikut:

Tabel 3. Jumlah Responden Menurut Tingkat Pendidikan

\begin{tabular}{|c|c|c|c|}
\hline $\begin{array}{c}\text { Tingkat } \\
\text { Pendidikan }\end{array}$ & $\begin{array}{c}\text { Jumlah } \\
\text { (orang) }\end{array}$ & $\begin{array}{c}\text { Percent } \\
\text { (\%) }\end{array}$ & $\begin{array}{c}\text { Valid } \\
\text { Percent }\end{array}$ \\
\hline PELAJAR & 90 & 58.06 & 58.06 \\
\cline { 2 - 4 } SARJANA & 56 & 36.12 & 36.12 \\
\cline { 2 - 4 } PENGANGGURAN & 9 & 5.80 & 5.80 \\
\hline Total & 155 & 100.0 & 100.0 \\
\hline
\end{tabular}

Jumlah responden menurut jenis pekerjaan dapat dilihat pada Tabel 4, berikut:

Tabel 4. Jumlah Responden Menurut Pekerjaan

\begin{tabular}{|c|c|c|c|}
\hline \multirow{2}{*}{ Pekerjaan } & $\begin{array}{c}\text { Jumlah } \\
\text { (orang) }\end{array}$ & $\begin{array}{c}\text { Percent } \\
\text { (\%) }\end{array}$ & $\begin{array}{c}\text { Valid } \\
\text { Percent }\end{array}$ \\
\hline Pegawai negri & 7 & 4.51 & 4.51 \\
\cline { 2 - 4 } Pegawai swasta & 11 & 7.09 & 7.09 \\
\cline { 2 - 4 } Wiraswasta & 22 & 14.19 & 14.19 \\
\cline { 2 - 4 } Pelajar & 90 & 58.06 & 58.06 \\
\cline { 2 - 4 } Tidak Bekerja & 25 & 16.12 & 16.12 \\
\hline Total & 155 & 100.0 & 100.0 \\
\hline
\end{tabular}

Frekuensi responden menurut tingkat pendapatan dapat dilihat pada Tabel 5, berikut:

Tabel 5. Jumlah Responden Menurut Pendapatan

\begin{tabular}{|c|c|c|c|}
\hline Pendapatan & $\begin{array}{c}\text { Jumlah } \\
\text { (orang) }\end{array}$ & $\begin{array}{c}\text { Percent } \\
(\%)\end{array}$ & $\begin{array}{c}\text { Valid } \\
\text { percent }\end{array}$ \\
\hline $\begin{array}{c}\text { < Rp.1.000,000- } \\
\text { Rp.1.000,000-1.500,000- } \\
\text { Rp. 1.500,000- }\end{array}$ & 90 & 58.06 & 598.06 \\
\cline { 2 - 4 } & 56 & 36.12 & 36.12 \\
\cline { 2 - 4 } & 9 & 5.80 & 5.80 \\
\hline Total & 155 & 100.0 & 100.0 \\
\hline
\end{tabular}

Pada tahap pertama ini dilakukan analisa tahap faktor-faktor yang berpengaruh terhadap produsen kamera ponsel Samsung. Pengolahan analisa faktor dilakukan dengan menggunakan Sofware SPSS.19 dan pada output, terlihat angka K-M-O Measure Of Sampling Adequancy (MSA) adalah 0,809 oleh karena angka MSA diatas 0,5 maka kumpulan Variabel tersebut dapat diproses lebih lanjut, selanjutnya tiap variabel dianalisis untuk mengetahui mana yang akan diproses lebih lanjut dan mana yang harus dikeluarkan. Tetapi pada proses tersebut tidak perlu ada variabel yang harus dikeluarkan karena tidak ada MSA dibawah 0,5 sehingga variabel penelitian dapat dilakukan analisis faktor, hal ini dapat dilihat pada tabel Output Analisa Faktor tabel Anti Image Matrices (AIM). Dimana jika AIM > 0,5 untuk tiap variabel maka dapat dilakukan analisis faktor lebih lanjut yaitu Rotasi faktor. Pada tabel AIM Kualitas 0,825 > 0,5, AIM kelengkapan produk 0,547 > 0,5, AIM model desain produk 0,086 >0,5, AIM nyaman digunakan dan keputusan pembelian 0,155 > 0,5. Karena Anti Image Matrices (AIM) dari keempat variabel diatas 0,5 maka dapat dilakukan analisis faktor dan dari analisis faktor keempat variabel tersebut dapat dibentuk 2 dimensi Tabel 6, berikut: 
Tabel 6. Matriks korelasi

\begin{tabular}{|c|c|c|c|c|c|}
\hline & & Kualitas & $\begin{array}{c}\text { Kelengkapan } \\
\text { Produk }\end{array}$ & Model Desain & $\begin{array}{c}\text { Nyaman } \\
\text { Digunakan }\end{array}$ \\
\hline Correlation & $\begin{array}{l}\text { Kualitas } \\
\text { Kelengkapan Produk } \\
\text { Model Desain } \\
\text { Nyaman Digunakan }\end{array}$ & $\begin{array}{l}1.000 \\
.801 \\
.662 \\
.693\end{array}$ & $\begin{array}{l}.801 \\
1.000 \\
.828 \\
.808\end{array}$ & $\begin{array}{c}.662 \\
.828 \\
1.000 \\
.846\end{array}$ & $\begin{array}{l}.693 \\
.808 \\
.846 \\
1.000\end{array}$ \\
\hline Sig. (1-tailed) & $\begin{array}{l}\text { Kualitas } \\
\text { Kelengkapan Produk } \\
\text { Model Desain } \\
\text { Nyaman Digunakan }\end{array}$ & $\begin{array}{l}.000 \\
.000 \\
.000\end{array}$ & $\begin{array}{l}.000 \\
.000 \\
.000\end{array}$ & $\begin{array}{l}.000 \\
.000 \\
.000\end{array}$ & $\begin{array}{l}.000 \\
.000 \\
.000\end{array}$ \\
\hline
\end{tabular}

a. Determinant $=.027$

Dari hasil analisis faktor tersebut didapat 2 dimensi untuk mengelompokan masing-masing atribut kamera ponsel Samsung dan dari hasil komponen matrik hasil dari proses rotasi memperlihatkan distribusi variabel yang lebih jelas jika dibandingkan tidak dilakukan rotasi. Dengan demikian ketujuh belas variabel telah direduksi menjadi hanya terdiri atas dua dimensi yang selanjutnya akan diproses lebih lanjut dalam analisis kluster, kedua dimensi tersebut adalah:

- Dimensi 1 terdiri atas kualitas, kelengkapan produk, garansi, kenyamanan penggunaan, dan model.

- Dimensi 2 terdiri atas harga, fitur, dan kecanggihan.

Untuk memberi nama segmen yang telah terbentuk digunakan teknik tak hirarki yang bertujuan untuk mengelompokan seluruh objek atau individu dalam kelompok, metode yang digunakan adalah pengelompokan tak hirarki K-Means Cluster. Metode ini bertujuan untuk mengelompokan objek sedemikian rupa sehingga jarak tiap pusat kedalam satu kelompok minimum. Dimana syarat pengambilan keputusan dari segmen ini adalah diambil nilai terbesar dari tiap segmen hasil akhir dari analisa kluster, terlihat pada lampiran final cluster center, harga, fitur, kenyamanan penggunaan, dan model memiliki nilai terbesar pada segmen 1 sehingga variabel tersebut termasuk dalam segmen 1 demikian seterusnya untuk keempat variabel lainnya dipilih nilai terbesar yang dimiliki dari dua segmen. Pembagian dua nilai segmen tersebut dapat dilihat pada Tabel7 dan Tabel 8, berikut:

Tabel 7. Jumlah Responden Dalam Tiap Segmen

\begin{tabular}{|c|c|c|}
\hline Segmen & Jumlah responden & Prosentase \\
\hline 1 & 97 & $62,58 \%$ \\
\hline 2 & 58 & $37,41 \%$ \\
\hline
\end{tabular}

Sumber : Hasil anlisis kluster

Tabel 8. Final kluster Centers

\begin{tabular}{|l|c|c|}
\hline \multirow{2}{*}{} & \multicolumn{2}{|c|}{ Kluster } \\
\cline { 2 - 3 } & 1 & 2 \\
\hline Kualitas & 17.65 & 8.20 \\
Kelengkapan Produk & 17.73 & 7.40 \\
Model Desain & 17.58 & 5.20 \\
Nyaman Digunakan & 21.97 & 7.80 \\
\hline
\end{tabular}

(sumber hasil : Final kluster centers, Lampiran 2)

Agar lebih mudah dalam menginterprestasikan karakteristik tiap segmen, maka jumlah responden yang masuk dalam masing-masing kategori variabel deskriptor akan dinyatakan dalam persentase. Persentase ini adalah persentase responden dalam kategori tentu terhadap seluruh responden dalam segmen yang bersangkutan. Deskripsi jumlah dan presentase bisa dilihat pada Tabel 9, berikut: 
Tabel 9. Deskripsi Tiap Segmen Pada Responden (Jumlah Orang)

\begin{tabular}{|c|c|c|c|}
\hline \multicolumn{2}{|c|}{ Variabel } & Segmen & $\underset{2}{\text { Segmen }}$ \\
\hline \multirow{2}{*}{ Jenis Kelamin } & \multirow{2}{*}{$\begin{array}{c}\text { Laki-laki } \\
\text { Perempuan }\end{array}$} & $0.84 \%$ & $54,19 \%$ \\
\hline & & $0.71 \%$ & $45,80 \%$ \\
\hline \multirow{3}{*}{ Usia } & \multirow{3}{*}{$\begin{array}{l}\text { 18-20 tahun } \\
\text { 20-30 tahun } \\
>30 \text { tahun }\end{array}$} & $0.101 \%$ & $65,16 \%$ \\
\hline & & $0.18 \%$ & $11,61 \%$ \\
\hline & & $0.36 \%$ & $23,22 \%$ \\
\hline \multirow{3}{*}{ Pendidikan } & \multirow{3}{*}{$\begin{array}{c}\text { Pelajar } \\
\text { Sarjana } \\
\text { Pengangguran }\end{array}$} & $0.90 \%$ & $58,06 \%$ \\
\hline & & $0.56 \%$ & $36,12 \%$ \\
\hline & & $0.9 \%$ & $5,80 \%$ \\
\hline \multirow{5}{*}{ Pekerjaan } & \multirow{5}{*}{$\begin{array}{c}\text { Pegawai negri } \\
\text { Pegawai swasta } \\
\text { Wiraswasta } \\
\text { Pelajar } \\
\text { Tidak Bekerja }\end{array}$} & $0.7 \%$ & $4,51 \%$ \\
\hline & & $0.11 \%$ & $7,09 \%$ \\
\hline & & $0.22 \%$ & $14,19 \%$ \\
\hline & & $0.25 \%$ & $16,12 \%$ \\
\hline & & $0.90 \%$ & $58,06 \%$ \\
\hline \multirow{3}{*}{ Pendapatan } & \multirow{3}{*}{$\begin{array}{c}<\text { Rp.1.000,000- } \\
\text { Rp.1.000,000-1.500,000- } \\
>\text { Rp. } 1.500,000-\end{array}$} & $0.90 \%$ & $58,06 \%$ \\
\hline & & $0.56 \%$ & $36,12 \%$ \\
\hline & & $0.9 \%$ & $5,80 \%$ \\
\hline
\end{tabular}

\section{Posisi Kamera ponsel Samsung Berdasarkan Persepsi Konsumen}

Berdasarkan tingkat kemiripan maka dilakukan pemetaan posisi kamera ponsel samsung terhadap ponsel kamera merek lain dengan menggunakan metode multidimensional scaling yang berdasarkan atribut yang terbentuk dari tiap faktor, maka diperoleh koordinat 3 kamera ponsel lain yang diperbandingkan dengan kamera ponsel Samsung dapat dilihat pada Tabel 10, berikut:

Tabel 10. Koordinat 4 ponsel kamera pada sumbu $X$ dan $Y$

\begin{tabular}{|l|c|c|}
\hline \multirow{2}{*}{ Hp Kamera } & \multicolumn{2}{|c|}{ Dimension } \\
\cline { 2 - 3 } & 1 & 2 \\
\hline SAMSUNG & -.595 & .962 \\
Sony & -2.639 & -2.246 \\
Oppo & 1.736 & -3.020 \\
Lenovo & -.212 & -.405 \\
\hline
\end{tabular}

(Sumber : final columm Coordinates, Hasil Analisa Multidimensional Scaling)

Selanjutnya hasil pengukuran persepsi konsumen ini digambarkan dalam suatu peta persepsi yang berisi posisi dari kamera ponsel Samsung yang diteliti. Penggambaran peta posisi tersebut digunakan untuk melihat kamera ponsel Samsung dimata konsumen relative sama dengan ponsel kamera lainya. persepsi dapat dilihat pada Gambar 1, berikut:

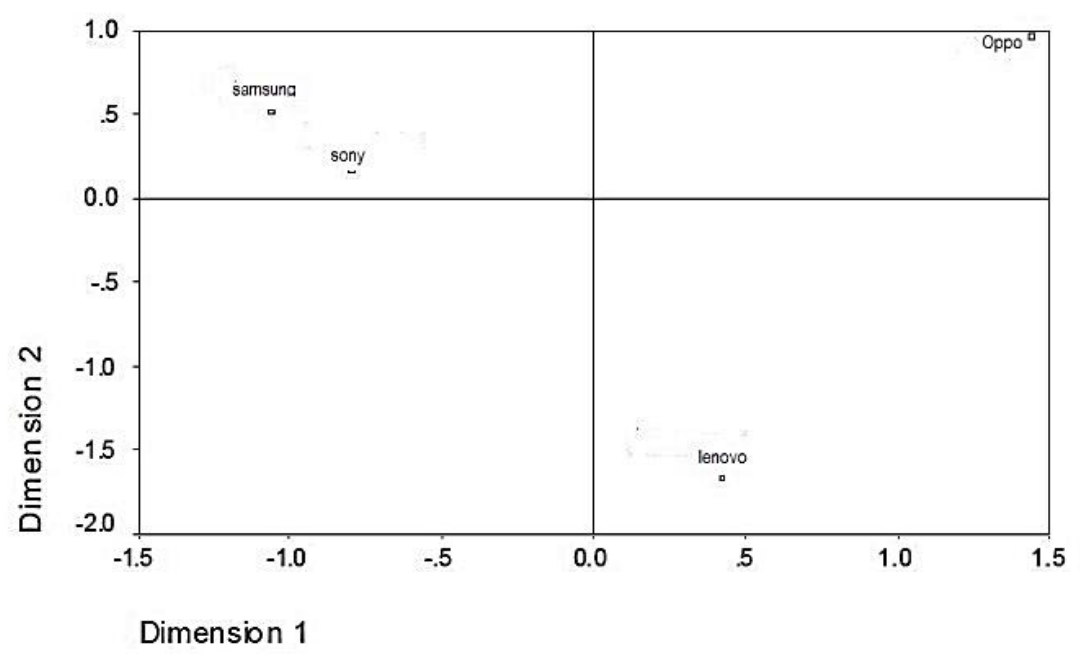

Gambar 1. Peta Posisi Kamera ponsel Samsung Dengan Dua Dimensi (Sumber : Hasil Multi Dimensional Scaling) 
Peta posisi diatas menunjukan posisi Kamera ponsel Samsung terhadap ponsel kamera digital. Dari peta posisi tersebut dapat diketahui jarak yang mencerminkan tingkat kemiripan antara kamera ponsel samsung. Semakin dekat jarak antara dua kamera maka semakin serupa pula kedua ponsel kamera tersebut di mata konsumen. Dari aspek pemasaran hal ini dapat di interprestasikan sebagai adanya persaingan yang ketat antara kamera ponsel Samsung dengan beberapa ponsel kamera lainya.

\section{Kesimpulan}

1. Dalam peta posisi Multi Dimensional Scalling terbentuk 2 dimensi dimana: Kamera ponsel Samsung berada pada dimensi 2 yaitu cenderung mengutamakan model desain, harga, kenyamanan penggunaan. Sedangkan ponsel kamera lain, yang dimaksudkan disini adalah $x_{1}, x_{2}$ dan $x_{3}$ lebih cenderung mengutamakan kualitas, kelengkapan produk.

2. Strategi-strategi yang dapat dilakukan produsen kamera ponsel Samsung adalah memberikan harga produk yang dapat dijangkau, menambah fitur yang lebih lengkap, serta memberikan kecanggihan yang terbaru pada kamera ponsel Samsung.

3. Ada pengaruh positif yang signifikan jenis-jenis asosiasi merek $\left(X_{1}\right)$, dukungan asosiasi merek $\left(X_{2}\right)$, kekuatasn asosiasi merek $\left(X_{3}\right)$, dan keunikan asosiasi merek $\left(X_{4}\right)$ kamera ponsel Samsung secara parsial terhadap loyalitas konsumen dengan nilai signifikansi dibawah 5\%. Selain itu, terdapat pengaruh dominan pada variabel jenis-jenis asosisi merek Kamera ponsel Samsung terhadap Loyalitas Konsumen dengan nilai kontribusi sebesar 40,7.

\section{Daftar Pustaka}

[1]. A. Aker, David Kuman., Marketing Research, Fifth Edition, 1995.

[2]. Andwi. S, Rendra., Analisis terhadap Beberapa kamera Samsung di Wilayah Tuban Berdasarkan Persepsi Konsumen dengan Metode Multi dimensional Scaling (MDS), Fakultas Teknologi Industri, Jurusan Teknik Industri, UPN "Veteran” Jatim, 2006.

[3]. Asri, Marwan., Marketing, AMPYKPN, Yogryakarta, 1991.

[4]. Buchari, Alma., Dasar-dasar bisnis dan pemasaran, CV.Alfabeta, Bandung, 1997.

[5]. Engel. dkk, Prilaku konsumen dan pemasaran, 1995.

[6]. James F. Enggel, Paul W. Miniard, Roger D. Black Well., Perilaku Konsumen, Edisi 6, Jilid 1 \& 2, 1995.

[7]. Kotler., Analisa Perencanaan implementasi dan Pengendalian, Edisi 9, Jilid l \& 2, Prehallindo, Jakarta, 1997.

[8]. Malhotra, (2010:354), Prosedur MDS dengan menggunakan data metric maupun non-metrik, 2010.

[9]. Philip., Manajemen Pemasaran: Analisis, Perencanaan, dan Pengendalian, Edisi 5. Mid 2, E-rlangga, Jakarta, 1991.

[10]. Sugiyono., Statistika Untuk Penelitian, CV. Alfabeta, Bandung, 2003.

[11]. Walpole, E. Ronald, Pengantar Statistika, Edisi 3, Penerbit PT. Ramedia Pustaka Utama, Jakarta. 